\title{
Evaluation of Indoor Environmental Quality Concerns Among Hospital Employees Working in a Radiology Department
}

Nancy C. Burton, PhD, MPH, MS, CIH

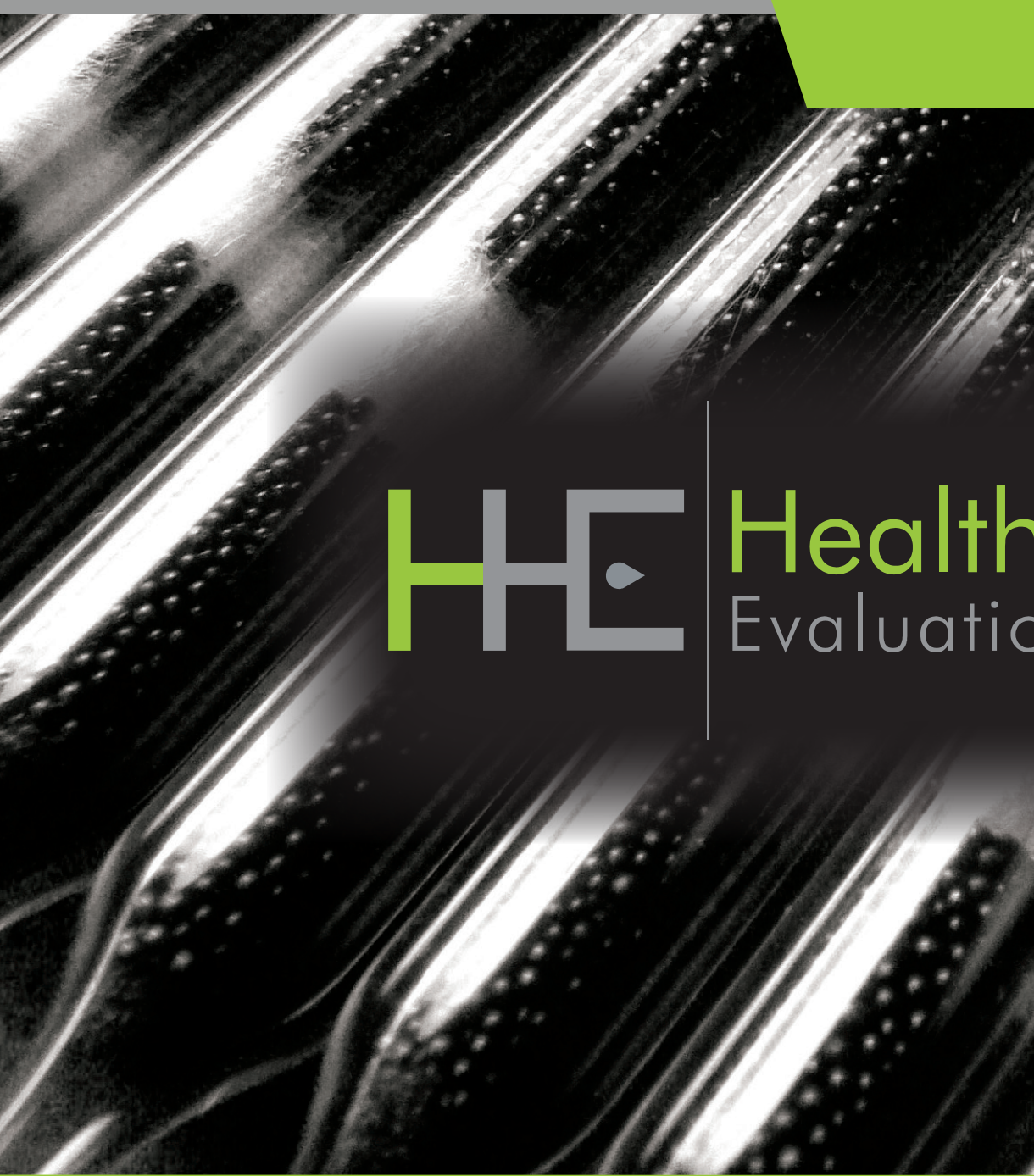

HHE Report No. 2016-0176-3326

September 2018 Loren Tapp, MD, MS 


\section{Contents}

Highlights.

Abbreviations ................................... iii

Introduction ............................................ 1

Methods .............................................. 1

Results and Discussion ........................ 3

Conclusions ........................................ 11

Recommendations........................... 12

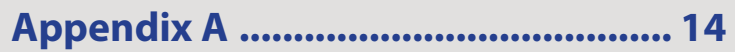

References ....................................... 20

Acknowledgements......................... 23

The employer is required to post a copy of this report for 30 days at or near the workplace(s) of affected employees. The employer must take steps to ensure that the posted report is not altered, defaced, or covered by other material.

The cover photo is a close-up image of sorbent tubes, which are used by the HHE Program to measure airborne exposures. This photo is an artistic representation that may not be related to this Health Hazard Evaluation. Photo by NIOSH. 


\section{Highlights of this Evaluation}

The Health Hazard Evaluation Program received a request from a union at a federal government run hospital. The union was concerned about indoor environmental quality, comfort issues, and particles coming out of the vents in the Radiology Department and the Magnetic Resonance Imaging Suites.

\section{What We Did}

- Visited the hospital in January-February 2017.

- Observed work processes, practices, and workplace conditions.

- Interviewed 30 Radiology/Magnetic Resonance Imaging Department employees about their health concerns.

- Reviewed illness and injury logs, ventilation system diagrams, a consultant's indoor environmental quality assessment report, and medical records.

- Took real-time air samples for carbon dioxide, carbon monoxide, temperature, and relative humidity.

- Looked at the heating, ventilation, and air-conditioning systems.

- Took bulk samples from different areas of the ventilation systems to characterize particles.

\section{What We Found}

We evaluated the indoor environmental quality in the Radiology Department and Magnetic Resonance Imaging Suites in a hospital. We found that air was bypassing the filtration systems and that the outdoor air intakes were at or below ground level. We recommended improving preventative maintenance on the ventilation systems and working with a mechanical engineer so that air supplied to the workspace meets current indoor environmental quality guidelines for health care facilities.

- Temperatures and carbon dioxide levels were within the recommended levels for indoor work environments.

- Carbon monoxide levels were well below occupational exposure limits.

- All relative humidity levels were below $60 \%$, and most were below $37 \%$.

- The outdoor air intake for the Radiology Department was located below the ground level in the front of the building. The outdoor air intake for the Magnetic Resonance Imaging Suites was at ground level. These do not meet current guidelines.

- The outdoor air intake filters for the Radiology Department ventilation system were damaged, and the gaskets were broken or missing, which allowed unfiltered air to enter the workspace.

- Several free-standing air filtration units needed filter changes, and there was no preventive maintenance program to change the filters. 
- The black particulates in the workplace contained soot, which indicated that exhaust particles were entering the workspace. Gray material in the ventilation systems was mostly cellulose.

- Over half of the employees reported being concerned about work exposures.

- Nine employees reported eye, nose, or throat irritation that improved away from work.

\section{What the Employer Can Do}

- Hire a licensed professional mechanical engineer to assess the outdoor air intakes for the ventilation system.

- Review the building's preventive maintenance plan with the goal of maintaining the ventilation system filter banks and gasket replacement.

- Start a preventive maintenance program to service the free-standing filtration units and ensure filters are changed according to schedule.

- Create a system for employees to report building concerns and to receive feedback on how issues were resolved.

\section{What Employees Can Do}

- Report work-related health concerns to your supervisor.

- See an occupational medicine physician about health problems you think may be related to work.

- Tell your supervisor when the ventilation system is not working properly.

- Recognize that some symptoms may not have a medical diagnosis. 


\section{Abbreviations}

$\begin{array}{ll}\text { ANSI } & \text { American National Standards Institute } \\ \text { ASHE } & \text { American Society for Healthcare Engineering } \\ \mathrm{CO}_{2} & \text { Carbon dioxide } \\ \mathrm{CO} & \text { Carbon monoxide } \\ \mathrm{HVAC} & \text { Heating, ventilation, and air-conditioning } \\ \text { IEQ } & \text { Indoor Environmental Quality } \\ \text { mg/m }{ }^{3} & \text { Milligrams per cubic meter } \\ \text { MERV } & \text { Minimum efficiency reporting value } \\ \text { MRI } & \text { Magnetic Resonance Imaging } \\ \text { NIOSH } & \text { National Institute for Occupational Safety and Health } \\ \text { OSHA } & \text { Occupational Safety and Health Administration } \\ \text { ppm } & \text { Parts per million } \\ \text { RH } & \text { Relative humidity }\end{array}$


This page left intentionally blank 


\section{Introduction}

The Health Hazard Evaluation Program received a request from a union representative at a hospital. The request concerned indoor environmental quality (IEQ), comfort issues including heat, and foreign particles coming out of the supply air vents in the Radiology Department and Magnetic Resonance Imaging (MRI) Suites. Employees reported symptoms such as eye, nose, and throat irritation and were concerned that breathing the particles would cause long-term health effects. We conducted our evaluation of the Radiology Department and MRI Suites from January 30 until February 2, 2017. We provided a written summary of our site visit and preliminary recommendations in February 2017.

\section{Background}

The hospital, constructed out of brick, was located among a complex of buildings built in the 1920s. A front addition, also constructed using brick, was added to the hospital in 1990. In the spring of 2016, Radiology Department employees began noticing black particles coming from the supply air ducts. Employees were also concerned about excessive heat in the Radiology Department, which they reported to reach $92^{\circ} \mathrm{F}$. Employees reported that patients in the radiology patient rooms were having breathing difficulties because of the high temperatures and humidity. They were also concerned that the high temperatures could have affected medical equipment.

The hospital's Radiology Department included the MRI Suites and was always open, but most services occurred during the daytime. Only emergencies were taken at night. Radiology Department staff provided direct patient care through diagnostic testing including x-rays, ultrasounds, computerized tomography (CT) scans, MRI scans and radiological procedures. Occasionally staff would also work in the Radiology Special Procedures area associated with the surgery department on the ground floor. At the time of our site visit, 41 employees worked in the area (35 union members, 2 registered nurses, and 4 management officials).

\section{Methods}

Our evaluation focused on the Radiology Department and the MRI Suites. Our objectives were to:

1. Assess the ventilation system and IEQ.

2. Assess employee concerns and if any employees had developed work-related symptoms or illnesses.

3. Characterize the black particles from the ventilation system.

During the site visit, we met with employer and employee representatives in the Radiology Department to discuss the HHE request. We observed work processes, practices, and workplace conditions, and spoke with employees. We used propylene glycol vapor to observe airflow patterns at the entrances to the Radiology Department and MRI Suites. We examined the two heating, ventilation, and air-conditioning (HVAC) units and ductwork that serviced the Radiology Department and MRI Suites. We collected bulk and wipe samples of material from the ventilation systems, ceiling air supply grilles, and ceiling return air grilles. 
We used dry Kimberly-Clark Kimwipes to collect wipe samples of black material from the air grilles. One bulk sample was analyzed by polarized light microscopy for particulates. Four bulk samples were analyzed for soot and particulates using transmission electron microscopy. Two bulk and two wipe samples were also analyzed for elemental carbon according to National Institute for Occupational Safety and Health (NIOSH) Method 5040 [NIOSH 2018]. Seven bulk samples were analyzed for elements, including metals, according to NIOSH method 7303 [NIOSH 2018].

We measured carbon dioxide $\left(\mathrm{CO}_{2}\right)$, temperature, relative humidity $(\mathrm{RH})$, and carbon monoxide (CO) using calibrated TSI Q-Trak ${ }^{\mathrm{TM}}$ Indoor Air Quality monitors in the Radiology Department, MRI Suites, and the Radiology Special Procedures unit. We compared indoor and outdoor $\mathrm{CO}_{2}$ concentrations to determine if indoor occupied spaces were adequately ventilated [ANSI/ASHRAE 2016]. $\mathrm{CO}_{2}$ is a normal constituent of exhaled breath and can be used as an indicator of whether enough outdoor air is being introduced into an occupied space to maintain body odors to an acceptable level. Indoor $\mathrm{CO}_{2}$ concentrations no greater than 700 parts per million (ppm) above outdoor $\mathrm{CO}_{2}$ concentrations will satisfy a substantial majority (about 80\%) of occupants [ANSI/ASHRAE 2016].

We measured temperature and RH because these characteristics can affect how employees perceive their indoor environment. Several factors affect thermal comfort including air movement, operative temperature, RH, clothing levels, and an individual's work activities. We compared the temperature and RH levels to American National Standards Institute/ASHRAE (ANSI/ASHRAE) thermal comfort guidelines [ANSI/ASHRAE 2017] as specified by ASHRAE's HVAC Design Manual for Hospitals and Clinics [ASHRAE 2013]. The ANSI/ASHRAE Standard 55-2017, Thermal Environmental Conditions for Human Occupancy, specifies conditions in which 80\% or more of the occupants would be expected to find the environment thermally comfortable [ANSI/ASHRAE 2017]. Additional guidelines for health care facilities are specified in the ANSI/ASHRAE/American Society for Healthcare Engineering (ASHE) Standard 170-2017 [ANSI/ASHRAE/ASHE 2017]. The ASHRAE (ANSI/ASHRAE) thermal comfort guidelines recommend RH be maintained below 65\%, and the U.S. Environmental Protection Agency recommends that RH be maintained below $60 \%$ (ideally $30 \%-50 \%$ ) to prevent mold growth. We used a thermal comfort tool developed by the Center for the Built Environment to compare our sample results to the ANSI/ASHRAE criteria (http://comfort.cbe.berkeley.edu/).

We measured $\mathrm{CO}$ as an indication of incomplete burning of carbon-containing materials such as gasoline or diesel fuel. The initial symptoms of $\mathrm{CO}$ poisoning may include headache, dizziness, drowsiness, or nausea. The lowest occupational exposure limit for $\mathrm{CO}$ is the American Conference of Governmental Industrial Hygienists' threshold limit value of 25 ppm over an eight-hour work shift [ACGIH 2018]. The United States Environmental Protection Agency has also established a concentration of interest of $9 \mathrm{ppm}$ of $\mathrm{CO}$ for an 8-hour exposure for nonindustrial environments [U.S. Environmental Protection Agency 2008].

We reviewed a consultant's IEQ report, Occupational Safety and Health Administration (OSHA) Form 300 Logs of Work-Related Injuries and Illnesses from 2013 through 2016, and blue print diagrams for the ventilation systems that serviced the Radiology Department and MRI Suites. We invited all 30 employees working in the Radiology Department and MRI Suites on the dates of our visit to participate in confidential medical interviews. We discussed 
work history, work practices, medical history, and health concerns. We asked employees an open-ended question about if they have had any health problems they thought were related to work, and an open-ended question about any other health concerns related to work. We also asked about specific symptoms they currently had during work hours and if the symptom(s) improved on days off work. If the employee reported that the symptom improved on days off work, we considered that symptom to be work-related.

\section{Results and Discussion}

\section{Ventilation System Inspections}

The Radiology Department and MRI Suites were served by two different HVAC units. The HVAC systems for both areas were variable air volume systems with ducted returns. The ductwork was not lined inside.

The HVAC unit for the Radiology Department unit had minimum efficiency reporting value (MERV) 8 pleated filters followed by MERV 14 bag filters. MERV ratings indicate the overall effectiveness of air filters. A higher MERV rating reflects a higher effective filtration, which means fewer dust particles and other airborne contaminants can pass through the filter. The filter banks for the system met the ANSI/ASHRAE/ASHE Standard 170-2017, Ventilation of Health Care Facilities guidelines of MERV 7 for the first filter bank and MERV 14 for the second filter bank [ANSI/ASHRAE/ASHE 2017]. The HVAC unit had a humidification system which used steam generated at the boiler plant as the water source. According to management, a Legionella prevention program had been implemented for the water systems and there were no additives in the steam.

We found that the outdoor air intake for the Radiology Department was about 10 feet below grade in the front of the hospital (Appendix A, Figure A1). It was located about 25 feet from pollutant sources such as exhaust from idling buses at the bus stop and vehicles dropping off and picking up individuals (Figure A2). We found snow in the ductwork of the outdoor air intake near the first set of air filters (Figure A3). The resulting moisture had caused the filters to become misshapen, resulting in air leakage around the filters (Figure A4). The filters were heavily loaded with dust, which means that they needed to be replaced. We found that the gaskets around the two filter banks and the HVAC doors were missing or broken, which contributed to air leakage around the filters (Figure A5). A dent in the second door at the HVAC unit prevented the door from sealing properly to the HVAC unit and allowed air to escape from the unit. We found particulates throughout the HVAC unit (Figure A6) including near the humidifier and cooling coils, which was located after the filter system. Debris and other particulates downstream of the filters in the HVAC system are evidence of ineffective filtration or leakage around air filters. We asked about but did not receive any information about a preventative maintenance program for the Radiology Department HVAC system.

The outdoor air intake for the MRI Suites was located slightly above ground level on the west side of the building near the ground level cooling coils (Figure A7). The MERV 8 pleated filters for the MRI Suites HVAC unit looked clean and we did not find evidence of air bypassing the filters. The MRI Suites also had a separate recirculating cooling system for the MRI equipment. 
We looked in all the rooms within the Radiology Department and MRI Suites for indicators of mold and moisture, including looking above ceiling tiles. We did not find any mold or moisture issues.

We checked airflow directionality for the Radiology Department and MRI Suites. Air flowed from the Radiology Department into the mechanical room where the HVAC unit was located. Air moved from the hallway and from the ultrasound rooms into the main Radiology Department waiting room. In the MRI Suites, air moved from the hallway into the waiting area and from the MRI work stations into the waiting area. This meets the requirement that air should flow into the waiting areas [ANSI/ASHRAE/ASHE 2017]. There are no requirements for pressure relationships for radiology areas for diagnostic and treatment rooms [ANSI/ASHRAE/ASHE 2017].

We observed free-standing air filtration units throughout the Radiology Department work area. Several units indicated that the filter needed to be changed. There was no preventative maintenance program in place to service these units. Excessively loaded and dirty filters obstruct airflow through the filters, which reduces their effectiveness in removing particulates. We observed black particulate around some of the supply air grilles and a build-up of material in several supply and return air grilles (Figure A9). This was additional evidence of material not being collected by the HVAC unit filters. We also observed that the staff handled patient gowns and exam table paper with each patient in the procedure rooms, which could be the source of extra particulates.

The air-conditioning for the Radiology Department reportedly failed in May 2016, leading to excessively warm temperatures in the department. During this time, the facility used portable fans and air-conditioning units and relocated staff when possible. The air conditioner was repaired in mid-June 2016 when a replacement part for the HVAC system was installed.

\section{Indoor Environmental Quality Measurements}

Table 1 summarizes the $\mathrm{CO}_{2}, \mathrm{CO}$, temperature, and $\mathrm{RH}$ levels we measured in the Radiology Department, MRI Suites, and the Radiology Special Procedures room in the surgical area.

None of the areas exceeded the ambient outdoor concentration of $\mathrm{CO}_{2}$ (about $400 \mathrm{ppm}$ ) by $700 \mathrm{ppm}$. This indicates that the HVAC units were providing sufficient outdoor air to maintain acceptable ventilation [ANSI/ASHRAE 2016]. CO, when detected, was at levels well below occupational exposure limits. However, the presence of $\mathrm{CO}$ indoors, even at low concentrations, may indicate that vehicle exhaust was brought into the building through the HVAC systems.

During our evaluation, the RH levels were below the maximum recommended level of $60 \%$ [ANSI/ASHRAE/ASHE 2017]. Using an average RH of about 17\% from the measured data, assuming an operative temperature range of $67^{\circ} \mathrm{F}$ to $73^{\circ} \mathrm{F}$, and occupants wearing typical clothing, the areas were within the recommended thermal comfort guidelines [ANSI/ASHRAE 2017]. However, very low RH levels may contribute to dry and irritated mucous membranes of the eyes and airways [Wolkoff and Kjaergaard 2007]. The Radiology Special Procedures area was colder than the other areas, but the staff also usually wore lab coats in this area. 
Table 1. Temperature, carbon dioxide, carbon monoxide, and relative humidity measurements in the hospital (January 31, 2017-February 1, 2017)

\begin{tabular}{lcccc}
\hline Location* & $\begin{array}{c}\text { Carbon dioxide } \\
(\mathrm{ppm})\end{array}$ & $\begin{array}{c}\text { Carbon monoxide } \\
(\mathrm{ppm})\end{array}$ & $\begin{array}{c}\text { Temperature } \\
\left({ }^{\circ} \mathrm{F}\right)\end{array}$ & $\begin{array}{c}\text { Relative humidity } \\
(\%)\end{array}$ \\
\hline $\begin{array}{l}\text { Radiology Department } \\
\text { Ultrasound Room } \\
\text { EO-13 }\end{array}$ & $423-601$ & $0-1.6$ & $67.1-73.0$ & $9.1-26.1$ \\
$\begin{array}{l}\text { Radiology Department } \\
\text { Ultrasound Room }\end{array}$ & $414-613$ & $0-0.7$ & $69.9-72.8$ & $7.9-21.6$ \\
$\begin{array}{l}\text { EO-36 } \\
\text { MRI Suites }\end{array}$ & $402-604$ & $0-0.6$ & $69.7-72.9$ & $8.1-20.7$ \\
$\begin{array}{l}\text { Reception Desk } \\
\text { MRI Suites } \\
\text { Control Room }\end{array}$ & $418-669$ & $0-0.8$ & $69.8-75.0$ & $8.3-20.6$ \\
$\begin{array}{l}\text { Radiology Special } \\
\text { Procedures† }\end{array}$ & $394-705$ & $0-0.3$ & $62.5-72.5$ & $8.3-36.7$ \\
Outdoors (a.m.) & 417 & 0 & 30 & 39 \\
\hline
\end{tabular}

${ }^{*}$ The sampling period was about 7:30 a.m. to 2:30 p.m. the next day (approximately 32 hours). †Located on ground floor

\section{Bulk Sample Analyses Results}

Microscopic analysis of the bulk material from the first filter bank floor of the ventilation system showed quartz (35\%), opaque material (10\%), carbonate $(10 \%)$, plastic $(10 \%)$, resin $(10 \%)$, rust $(5 \%)$, clay particles $(5 \%)$, biotite $(3 \%)$, mold $(3 \%)$, muscovite $(3 \%)$, insect body parts $(2 \%)$, pollen $(1 \%)$, welding material $(1 \%)$, plant trichomes $(1 \%)$, and tourmaline $(1 \%)$. Quartz is one of the most common components of soil and soil dust. The materials identified in the samples are commonly found in building materials (plastic, resin, rust, and welding material) and the others from the outdoor environment.

Antimony, calcium, iron, magnesium, potassium, and zinc were among the most abundant elements present in the seven bulk samples (Table 2). Low levels of chromium, copper, lead, nickel, tin, and titanium were detected in all of the samples. Based on the age of the medical center complex, the presence of low levels of lead on-site would not be unexpected because of its historic use in paint and vehicle fuel. There are no occupational exposure limits for bulk samples. A recent review of contaminants found in the hospital environment identified similar elements to those identified in our samples [Ghanizadeh and Godini 2018]. 
Table 2. Results for elements in bulk dust samples, in milligrams per kilogram

\begin{tabular}{|c|c|c|c|c|c|c|c|}
\hline Element & $\begin{array}{l}\text { Outdoor } \\
\text { air } \\
\text { intake }\end{array}$ & $\begin{array}{l}\text { HVAC - } \\
\text { below 1st } \\
\text { set of } \\
\text { filters }\end{array}$ & $\begin{array}{l}\text { HVAC - } \\
\text { below 2nd } \\
\text { set of } \\
\text { filters }\end{array}$ & $\begin{array}{c}\text { HVAC } \\
\text { room - } \\
\text { water } \\
\text { damage } \\
\text { area }\end{array}$ & $\begin{array}{c}\text { MRI } \\
\text { supply } \\
\text { vent by } \\
\text { changing } \\
\text { room }\end{array}$ & $\begin{array}{l}\text { Ultrasound } \\
\text { room } \\
\text { return }\end{array}$ & $\begin{array}{c}\text { Door of } \\
\text { second } \\
\text { filter } \\
\text { bank }\end{array}$ \\
\hline Antimony & 5,200 & 24,000 & 8,400 & 4,900 & 2,600 & 1,200 & 6,300 \\
\hline Aluminum & 31 & 30 & ND & 36 & ND & ND & [43] \\
\hline Arsenic & [9] & [8.7] & ND & [9.0] & ND & ND & [26] \\
\hline Barium & 36 & 86 & 160 & 150 & 110 & 58 & 530 \\
\hline Beryllium & {$[0.1]$} & ND & ND & [0.09] & [0.58] & ND & ND \\
\hline Cadmium & 11 & 9.2 & [6.6] & 18 & [3.6] & ND & 14 \\
\hline Calcium & 12,000 & 10,000 & 11,000 & 19,000 & 14,000 & 8,000 & 28,000 \\
\hline Chromium & 160 & 110 & 370 & 120 & 49 & 21 & 160 \\
\hline Cobalt & 9.1 & 8.8 & 9.1 & 8.5 & 3.2 & ND & 11 \\
\hline Copper & 140 & 190 & 300 & 3,500 & 350 & 140 & 480 \\
\hline Iron & 99,000 & 76,000 & 31,000 & 140,000 & 8,000 & 1,400 & 14,000 \\
\hline Lanthanum & ND & ND & ND & ND & ND & ND & ND \\
\hline Lead & 52 & 56 & 140 & 280 & 58 & [18] & 120 \\
\hline Lithium & [1.4] & 2.7 & 4.9 & {$[0.61]$} & [3.3] & ND & 9.4 \\
\hline Magnesium & 3,400 & 4,100 & 5,400 & 2,500 & 2,300 & 1,000 & 12,000 \\
\hline Manganese & 510 & 410 & 280 & 360 & 89 & 27 & 340 \\
\hline Molybdenum & 9.9 & 18 & 12 & 9.3 & 4.9 & ND & 16 \\
\hline Nickel & 91 & 56 & 120 & 69 & 51 & 19 & 61 \\
\hline Phosphorus & 620 & 1,800 & 2,400 & 3,800 & 550 & 960 & 1,900 \\
\hline Potassium & 710 & 1,700 & 1,400 & 2,300 & 3,900 & 3,400 & 4,300 \\
\hline Selenium & ND & ND & ND & ND & ND & ND & ND \\
\hline Silver & ND & [1.3] & [130] & ND & [2.2] & {$[4.0]$} & [3.8] \\
\hline Strontium & 38 & 120 & 410 & 160 & 33 & 17 & 450 \\
\hline Tellurium & 24 & [6.9] & ND & 31 & ND & ND & ND \\
\hline Thallium & ND & ND & ND & ND & ND & ND & ND \\
\hline Tin & 11 & 16 & 42 & 130 & [13] & [11] & 45 \\
\hline Titanium & 270 & 120 & 180 & 5.3 & 64 & 23 & 340 \\
\hline Vanadium & 25 & 24 & 62 & 110 & 17 & [6.1] & 45 \\
\hline Yttrium & 2.8 & 2.1 & 2.9 & 2.3 & 1.4 & 0.88 & 5.8 \\
\hline Zinc & 23,000 & 110,000 & 180,000 & 6,700 & 3,300 & 960 & 110,000 \\
\hline Zirconium & ND & 0.98 & 7.7 & ND & 120 & 160 & 9.8 \\
\hline
\end{tabular}

[ ] = This result is between the limit of detection and limit of quantitation; more uncertainty is associated with this level.

$\mathrm{ND}=$ The element was not detected at a limit of detection of 58 milligrams per kilogram or lower. 
The four samples analyzed for elemental carbon showed high organic material content, which was often found with a high concentration of cellulose. These four samples were from the inside of the door to the second filter bank for the Radiology Department HVAC system, the MRI bathroom return, a wipe sample of the MRI file room supply of the black material on the metal supply air grille, and a wipe sample of the black material on the Radiology Department breakroom metal supply air grille. The door of the second filter bank (Figure A5) showed the highest amount of elemental carbon. The wipe sample from the MRI supply diffuser showed the lowest amount of elemental carbon, but was black in color, which suggested the presence of soot.

Four additional bulk samples were submitted for microscopic analysis. The samples were black material from the MRI changing area, fuzzy material from an ultrasound room supply grille, black material from the MRI file room, and fuzzy material from the Radiology Department breakroom supply grille. The two samples with fuzzy material were similar based on polarized light microscopy. They were found to contain cellulose, synthetic fibers, cornstarch, and mineral and plastic fragments. Transmission electron microscopy showed that the other two samples of black material contained soot and soot-like particles (Figures A10 and A11). The energy dispersive x-ray spectroscopy showed mostly carbon, with small amounts of oxygen, silica, calcium, and aluminum.

The presence of elemental carbon and soot in the samples indicated that diesel exhaust was likely entering the workspace through the HVAC system. Diesel exhaust is a complex mixture of various gases and fine particles. Diesel exhaust is typically black in color with a low odor threshold (odors easily detected at low concentrations) and contains more than 40 toxic compounds [U.S. Environmental Protection Agency 2002]. The particles mainly consist of organic carbon compounds adsorbed onto cores of microscopic elemental carbon [Birch 2018].

\section{Document Review}

We reviewed a June 2016 consultant's report provided by management. The consultant conducted an IEQ assessment in May 2016 in the Radiology Department. They collected air samples for mold (using spore traps), particulates, and volatile organic compounds and tape lift samples for particulate identification. They also measured indoor temperature, $\mathrm{CO}, \mathrm{CO}_{2}$, and $\mathrm{RH}$.

The air samples collected on spore traps showed similar species and concentrations of mold when compared to air samples collected outdoors. Real-time air concentrations of particulates were low in the sampled areas with total particulate concentrations ranging from 0.003 milligrams per cubic meter $\left(\mathrm{mg} / \mathrm{m}^{3}\right)$ to $0.037 \mathrm{mg} / \mathrm{m}^{3}$. Low levels of acetone, $\mathrm{n}$-butane, 2-butanone, chloromethane, cyclohexene, ethanol, ethyl acetate, n-heptane, n-hexane, isopropyl alcohol, 2,2,4-dimethylpentane, and toluene were detected in the four evacuated summa canister air samples. These results were well below any applicable occupational exposure limits.

Microscopic analysis of tape lift samples showed skin cell fragments, cellulose material, opaque particles, soil, and other generic biological particles. Temperatures ranged from $72.2^{\circ} \mathrm{F}-80.8^{\circ} \mathrm{F}$, which were elevated when compared to ANSI/ASHRAE guidelines. CO concentrations ranged from 0.4 ppm to $1.1 \mathrm{ppm} ; \mathrm{CO}_{2}$ levels were $524 \mathrm{ppm}$ to $648 \mathrm{ppm}$; and $\mathrm{RH}$ ranged from $34.8 \%$ to $44 \%$. These were within acceptable limits for the days monitored according to ANSI/ASHRAE guidelines. These findings are similar to those observed during our site visit. 
We reviewed the hospital's OSHA 300 logs for years 2013 through 2016. These logs were for the entire hospital. Results are shown in Table 3.

Table 3. Number of OSHA 300 injury and illness log entries for all hospital employees for years 2013 through 2016; by injury and illness type

\begin{tabular}{lcccc}
\hline Type of entries & \multicolumn{4}{c}{ Number of entries } \\
\cline { 2 - 5 } & 2013 & 2014 & 2015 & 2016 \\
\hline Total OSHA 300 Log & 53 & 79 & 70 & 82 \\
entries & 15 & 25 & 28 & 16 \\
Slips, trips, falls & 17 & 24 & 23 & 23 \\
Sprains and strains & 8 & 8 & 10 & 11 \\
Fracture, contusion, & & & & \\
$\quad$ laceration, abrasion, & 3 & 3 & 2 & 8 \\
$\quad$ burn & 0 & 3 & 2 & 2 \\
Needle sticks & 3 & 1 & 2 & 6 \\
Blood/body fluid exposure & 1 & 0 & 0 & 0 \\
Injury from patient & 1 & 0 & 0 & 1 \\
Allergic reaction & 0 & 0 & 1 & 2 \\
Chest pain & & 1 & & 1 \\
Respiratory distress or & 0 & 0 & 1 & 2 \\
$\quad$ respiratory symptoms & 0 & 14 & 1 & 10 \\
Chemical exposure & 5 & & & \\
Stress disorder & & & & \\
Other & & &
\end{tabular}

Overall, slips, trips, falls, strains, and sprains were the most common entries for all years. One entry in July 2015 involved an HVAC equipment operator with respiratory distress due to extreme temperatures and a traumatic event in the mechanical equipment room. Of two respiratory entries in February 2016, one was a nurse in the outpatient clinic reporting persistent cough "due to OR (operating room) air quality" and the other was a medical support staff in administrative offices reporting respiratory symptoms "due to environment." None of the respiratory disorders, chemical exposures, allergic reactions, stress related disorders, chest pain, or dizziness entries were among employees located in the Radiology Department or MRI Suites.

\section{Interviews}

We interviewed all 30 employees working in the Radiology Department and MRI Suites on the dates of our visit, including 13 males and 17 females. We did not interview employees from the nuclear medicine department. The average age of employees was 53 years (range: 30-67 years), and the average amount of time in their current job was 9 years (range: 1 month-30 years).

Two of the 30 interviewed employees were supervisory staff. Of the remaining 28 employees, there were twelve radiology technicians working in X-ray, CT, and/or MRI Suites departments, seven administrative or clerical staff, four radiologists, four ultrasound technicians, and one 
nurse. Three of the 12 radiology technicians worked half-time on the first floor assisting with special procedures in either the operating suites or the intervention room or both.

Ten of the 30 employees reported potential work-related health problems when asked an open-ended question, including throat irritation (3), eye irritation (2), runny nose (2), cough from post-nasal drip (1), chronic sinusitis/sinus infections (2), headaches (1), psoriasis/itchy skin (1), and latex allergy (1). Some reported more than one symptom/health problem. Onset of symptoms was reported by the ten employees to be 2014 (4), 2010 (2), when they moved into the basement (2), and unable to remember (2). Three employees sought medical attention for health problems they believed were work-related, including allergic reactions/ hives (1), fibromyalgia and arthritis (1), and latex allergy (1). We reviewed employee health records for these three employees; we found too little information in the records to make any conclusions about cause. Three of the ten also reported being transferred to a different job location. No employees submitted workers' compensation claims.

We asked about history of atopy; ten reported a history of allergic rhinitis, six reported asthma, and one reported atopic eczema. Of the 30 employees, 20 never smoked, seven were former smokers, and three were current smokers.

We asked employees if they currently had any of a list of specific symptoms during work hours and, if so, did the symptom improve on days off work (Table 4). Nine employees reported eye, nose, or throat irritation during work hours that improved on days off. These were the most commonly reported work-related symptoms. No employees reported chest tightness or shortness of breath. Six employees reported having rash in the prior month; one of the six reported itchy skin and redness to wrists only at work, suggesting a possible association with work.

Table 4. Number of Radiology Department and MRI Suites employees $(n=30)$ reporting symptoms and their relationship to work, by symptom type

\begin{tabular}{lcc}
\hline Symptoms & $\begin{array}{c}\text { Employees reporting symptoms } \\
\text { Number (\%) }\end{array}$ & $\begin{array}{c}\text { Employees reporting symptom } \\
\text { improved away from work } \\
\text { Number (\%) }\end{array}$ \\
\hline Eye irritation & $10(33)$ & $4(13)$ \\
Throat irritation & $7(23)$ & $5(17)$ \\
Nasal irritation & $4(13)$ & $4(13)$ \\
Nausea & $3(10)$ & $2(7)$ \\
Cough & $3(10)$ & $1(3)$ \\
Dizziness & $3(10)$ & 0 \\
Headache & $2(7)$ & $*$ \\
Wheeze & $1(3)$ & 0 \\
\hline
\end{tabular}

${ }^{*}$ no information on work-relatedness was obtained 
Of the 30 employees, 17 reported concerns about work exposures. These concerns included poorly maintained HVAC system, poor ventilation, and poor air quality (7), particles and/or dust in and on vents (7), temperature extremes (2), diesel fumes entering HVAC intake (2), poor communication and follow-up on concerns (2), and respiratory illness of a fellow employee thought to be due to poor air quality (1). Some employees had more than one concern.

Of the 30 employees, 16 reported that their work environment had comfortable temperature and humidity levels. Several reported feeling cold at work, but thought that it was needed to maintain the radiological equipment. Several employees described an incident in the summer of 2016 in which the air conditioner failed and the work area in the basement became very hot. They reported that there was no follow-up on what was wrong or when it was to be fixed. Employees felt like their concerns were not addressed. A few employees reported lack of trust in management and that they thought the administration was involved in "covering up facts."

Seventeen of 30 employees noticed black particles in their work area, including on vents, walls, ceiling tiles, and floor that reappeared a few days after being cleaned. Eight reported odors including diesel or other exhaust fumes, mulch, fertilizer, or other "strong" odors; two reported having to step out of the work area because of nausea.

Odors may produce health symptoms by three mechanisms. First, symptoms can be induced by exposure to odorants at levels that also cause irritation. Therefore, irritation, rather than the odorant, is the cause of the symptoms. Second, health symptoms from odorants at nonirritant concentrations, such as hydrogen sulfide, can be due to innate or learned aversions. Third, symptoms may be due to a co-pollutant, such as endotoxin, that is part of an odorant mixture [Schiffman and Williams 2005]. It is possible that symptoms reported by facility employees could be associated with all three mechanisms but also could be associated with nonoccupational factors. The unfiltered air entering the workspace from the ventilation system could also contain odors from sources outside such as yard work activities and vehicle exhaust. In persons with existing health problems, such as asthma or chronic respiratory problems, odors can also worsen pre-existing symptoms. For example, odors have been found to affect the physiological and psychological responses of individuals with asthma [Beach et al. 1997].

Several employees had fears that their work environment was not safe and that employees were inhaling contaminants that could cause long-term health effects. Some were concerned that asbestos or other toxic compounds from abandoned buildings might blow into their air intake. These fears were amplified when a former employee became ill with respiratory symptoms and left employment apparently from health problems that employees believed were due to the work environment. Because the exposures we identified were short-term and occurred intermittently, it is very unlikely that employees would have long-term health effects from inhaling contaminants.

Requestors reported respiratory and sinus symptoms they thought were related to workplace exposures and expressed concerns about the IEQ of the building. In the scientific literature, most of the reported symptoms, such as eye and throat irritation, nasal congestion, and sneezing, have been reported frequently during IEQ investigations of buildings in nonindustrial settings such as schools, hospitals, and office buildings [Brightman et al. 2008]. Typically, employees suspect a workplace cause because their symptoms appear to be worse while at work and better when away from work. In our experience, some of these symptoms 
may be related to poor IEQ, such as problems with building airflow and temperature as well as the presence of low levels of chemicals from office furnishings, office machines, cleaning products, personal hygiene products, and structural components of the building [Mendell 1993]. The problems we identified with the location and maintenance of the Radiology Department HVAC system, which allowed unfiltered air to enter the workspace, could have contributed to symptoms. However, the same symptoms are commonly experienced by people outside of the workplace. Some symptoms that began coincidentally with IEQ concerns can be explained by medical conditions that are not related to work, such as respiratory infections and allergies. For these reasons, the causes of the reported symptoms cannot be specifically attributed to workplace exposures.

Diesel exhaust exposure has been associated with acute health effects, such as eye, nose, throat, and lung irritation; cough; headache; lightheadedness; and nausea [Gamble et al. 1987; Pronk et al. 2009; Reger and Hancock 1980; Sydbom et al. 2001]. Diesel exhaust exposure has also been associated with lung inflammation, aggravated asthma and other chronic respiratory conditions, increased allergenic responses, and lung cancer [International Agency for Research on Cancer 2012; Sydbom et al. 2001; Ulfvarson and Alexandersson 1990]. Although we found evidence that diesel exhaust and soot were likely entering the workspace through the ventilation system, these exposure levels would be very low compared to industrial settings. Whether a person experiences these acute or chronic health effects depends on the duration and magnitude of the exposures and on individual susceptibility.

The employees believed that they were not receiving adequate information from managers regarding how potential hazards in the building were being addressed. There was no formal IEQ management program in place to provide information to employees. Employees reported that much of the information they received regarding potential exposures and management's efforts to address them were based on office conversation. Such informal communication can result in mixed messages, rumors, or other misinformation, which can negatively impact workplace stress, frustration, and trust in management [Boxer 1990]. It is also important that the employer regularly consult with employees about their health and safety concerns and explain to employees how the concerns will be addressed or why they cannot be addressed. Doing so may strengthen positive perspectives of the employer's willingness to care for the well-being of the employees and lead to improvements in safety systems [Vecchio-Sudus and Griffiths 2004].

\section{Conclusions}

Employees reported concerns about poor ventilation and black particles from vents in their workplace and how they were potentially affecting their health. We found evidence of elemental carbon, soot consistent with diesel exhaust particles, and low levels of CO entering in the work areas. We also found that the HVAC units' outdoor air intakes were at or below ground level. Inspection of the HVAC unit serving the Radiology Department showed that moisture was affecting the fit of the frames in the first filter bank. We found broken and missing gaskets inside the HVAC unit including the second set of filters. This allowed outdoor air to bypass the filter systems and enter the workspace. The perception of the lack of management action in addressing these concerns may be linked to why some employees expressed distrust in the employer's willingness to look out for the well-being of employees. 


\section{Recommendations}

On the basis of our findings, we recommend the actions listed below. We encourage the medical center to use a labor-management health and safety committee or working group to discuss our recommendations and develop an action plan. Those involved in the work can best set priorities and assess the feasibility of our recommendations for the specific situation at the medical center.

Our recommendations are based on an approach known as the hierarchy of controls. This approach groups actions by their likely effectiveness in reducing or removing hazards. In most cases, the preferred approach is to eliminate hazardous materials or processes and install engineering controls to reduce exposure or shield employees. Until such controls are in place, or if they are not effective or feasible, administrative measures and/or personal protective equipment may be needed.

\section{Engineering Controls}

Engineering controls reduce employees' exposures by removing the hazard from the process or by placing a barrier between the hazard and the employee. Engineering controls protect employees effectively without placing primary responsibility of implementation on the employee.

1. Replace the filters in the Radiology Department HVAC unit and repair or replace the HVAC system gaskets.

2. Consult with a licensed professional mechanical engineer to reconfigure the outdoor air for the two HVAC systems so that the two intakes are located 6 meters above ground level, as recommended by ASHRAE intakes for hospital and medical facilities [ASHRAE 2013].

\section{Administrative Controls}

The term administrative controls refers to employer-dictated work practices and policies to reduce or prevent hazardous exposures. Their effectiveness depends on employer commitment and employee acceptance. Regular monitoring and reinforcement are necessary to ensure that policies and procedures are followed consistently.

1. Improve the maintenance program for the hospital ventilation system by establishing a freestanding air filtration and HVAC filter change-out schedule on the basis of use conditions and manufacturer recommendations. In addition, the maintenance program should include critical evaluation, and prompt repair when needed, of the working components of these systems.

2. Start an IEQ management plan. Select an IEQ manager or administrator with clearly defined responsibilities, authority, and resources. This individual should have a good understanding of the building's structure and function and should be able to effectively communicate with the various tenants. This proactive approach can help prevent IEQ problems from occurring. If you would like more information on IEQ, including the documents "Building Air Quality-A Guide for Building Owners and Facility Managers" and "Building Air Quality Action Plan" see 
http://www.cdc.gov/niosh/topics/indoorenv/. The basic elements of a good IEQ plan include the following:

- Properly operating and maintaining the ventilation equipment.

- Overseeing the activities of occupants and contractors that affect IEQ (e.g., housekeeping, pest control, maintenance).

- Ensuring effective and timely communication with tenants regarding IEQ.

- Educating employees about their responsibilities in relation to IEQ.

- Proactively identifying and managing projects that may affect IEQ (e.g., leaking roof, damaged floor tiles, water leaks, renovation).

3. Improve communication between managers and employees regarding responses to employee health and safety concerns. A supervisor or manager who is sensitive to the employees' concerns should communicate directly with those who report health and safety concerns. Points to consider include:

- Actively listening to employees' concerns in a nonjudgmental manner. Employees should feel that their concerns are taken seriously.

- Regularly informing employees of exactly what steps are being taken to assess the problem, what has been determined, and what remains to be determined. A combination of written reports and face-to-face meetings are valuable.

- Routinely share information with employees rather than waiting until a cause of the problem is discovered; this will reduce the chance of distorted rumors.

4. Track and investigate work-related complaints or problems reported by employees, and share the findings with employees.

5. Encourage employees with health concerns related to their workplace to seek evaluation and care from a physician who is residency trained and/or board certified in occupational medicine and is familiar with the types of exposures employees may have had and their health effects. The Association of Occupational and Environmental Clinics (http://www.aoec.org) and the American College of Occupational and Environmental Medicine (http://www.acoem.org) maintain lists of their members.

6. Replace exam table paper and patient gowns with products that have reduced cellulose content to reduce shedding of particulates. 


\section{Appendix A: Figures}

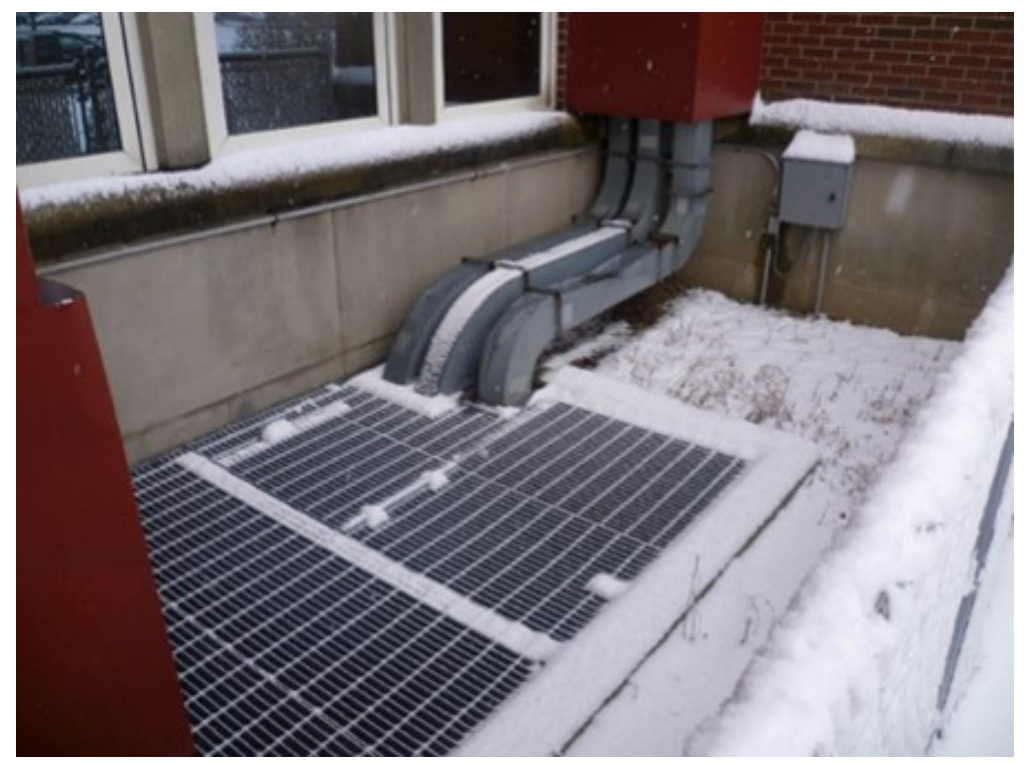

Figure A1. Outdoor air intake for Radiology Department ventilation unit, which was below grade. Photo by NIOSH.

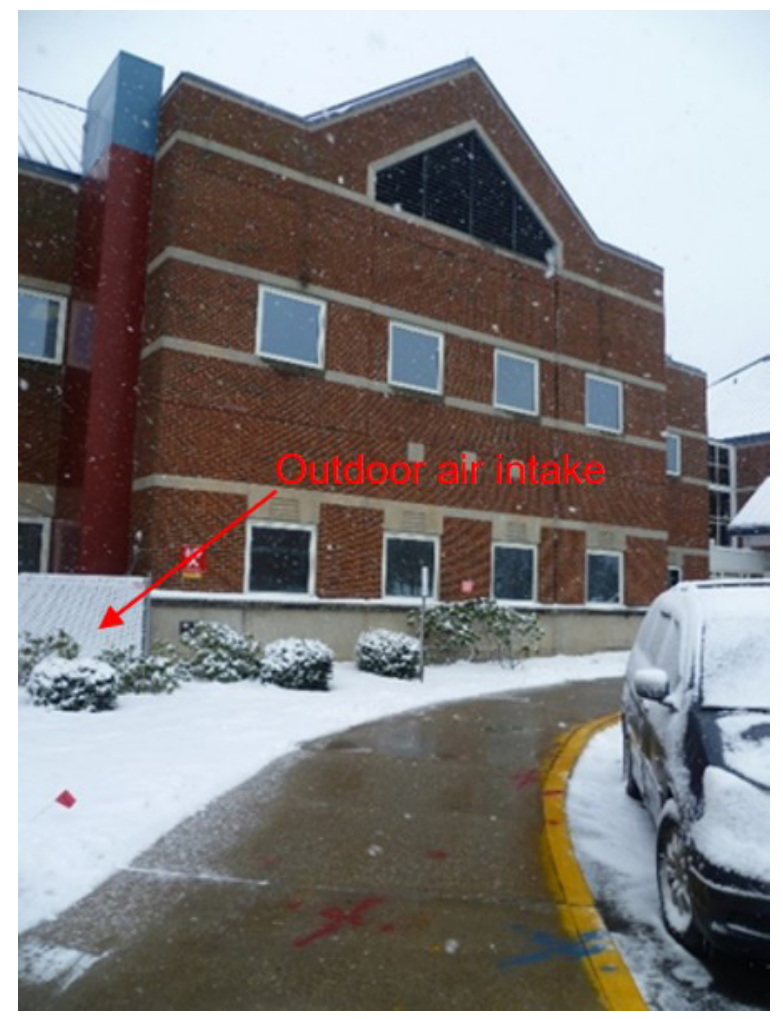

Figure A2. View of potential pollutant sources for outdoor air intake. Photo by NIOSH. 


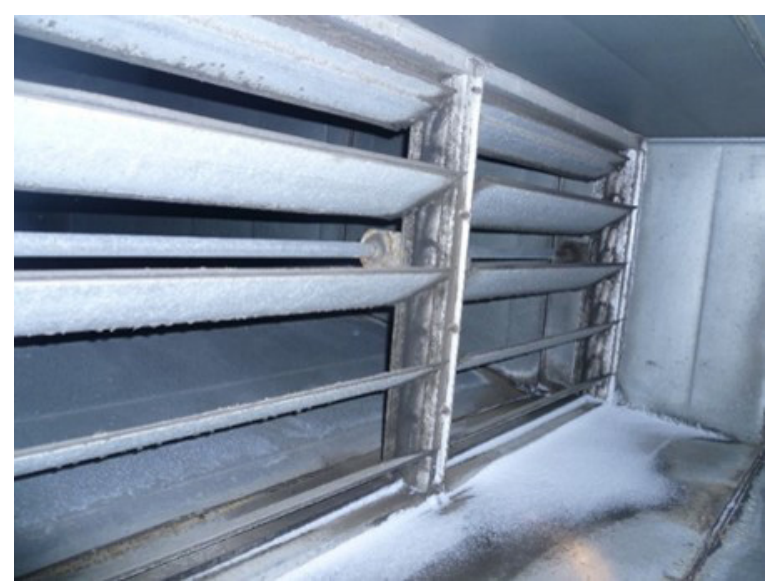

Figure A3. Snow on the downstream side of the outdoor air intake louvers of the Radiology Department HVAC unit. Photo by NIOSH.

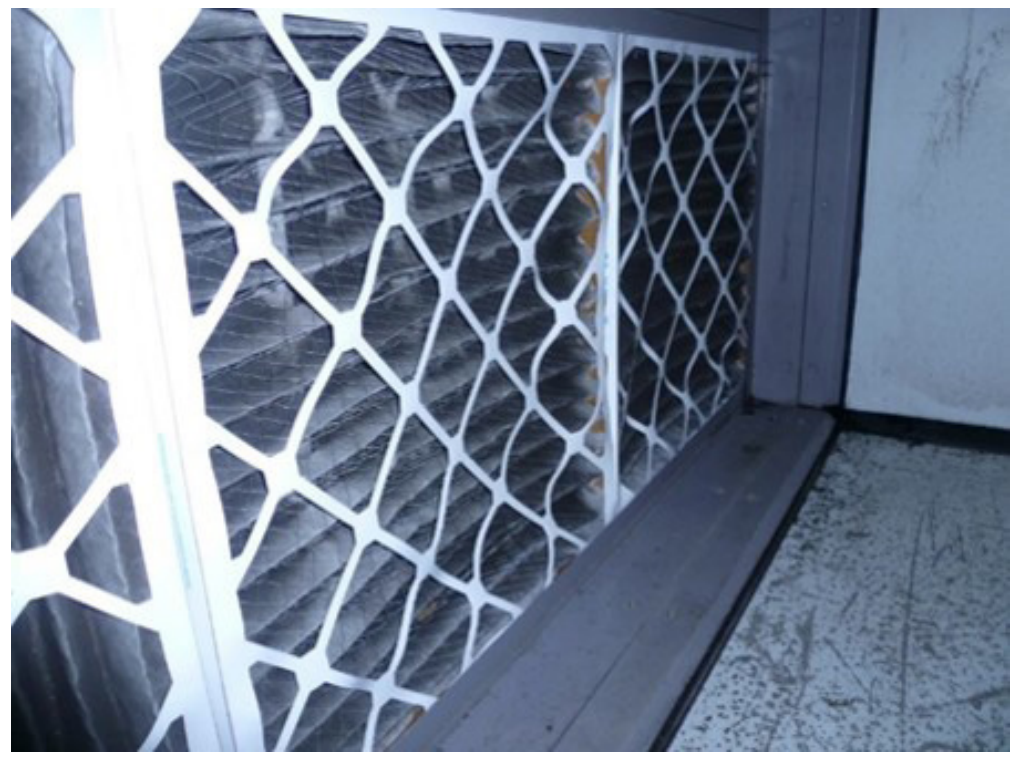

Figure A4. First bank of filters showing that the filters were bent, poorly fitting, and had damaged filter frames due to moisture. Photo by NIOSH. 


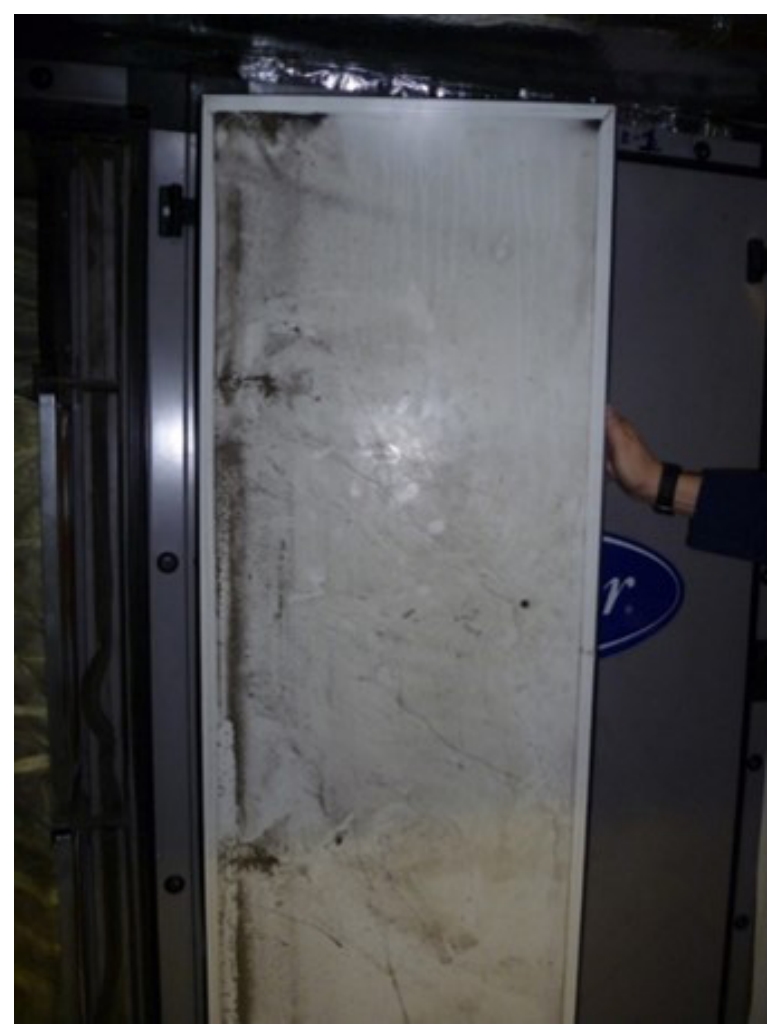

Figure A5. Door for second filter bank showing particles that had by-passed the filters. Photo by NIOSH.

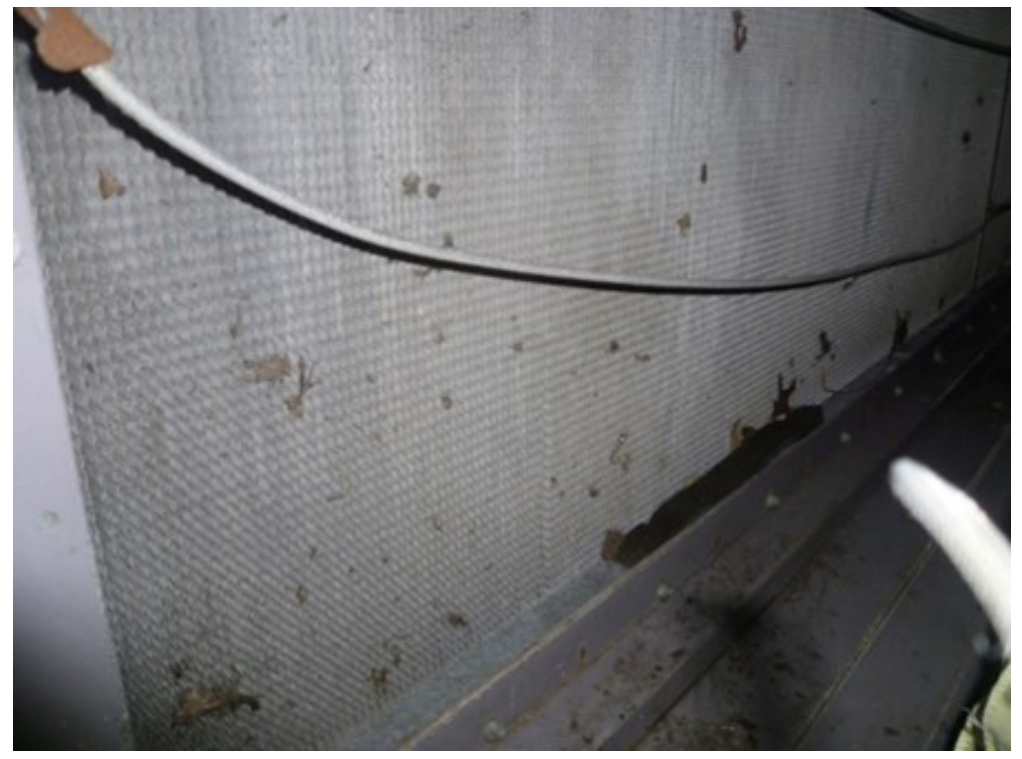

Figure A6. Debris including pieces of plant material on the cooling coils after the two banks of filters. Photo by NIOSH. 


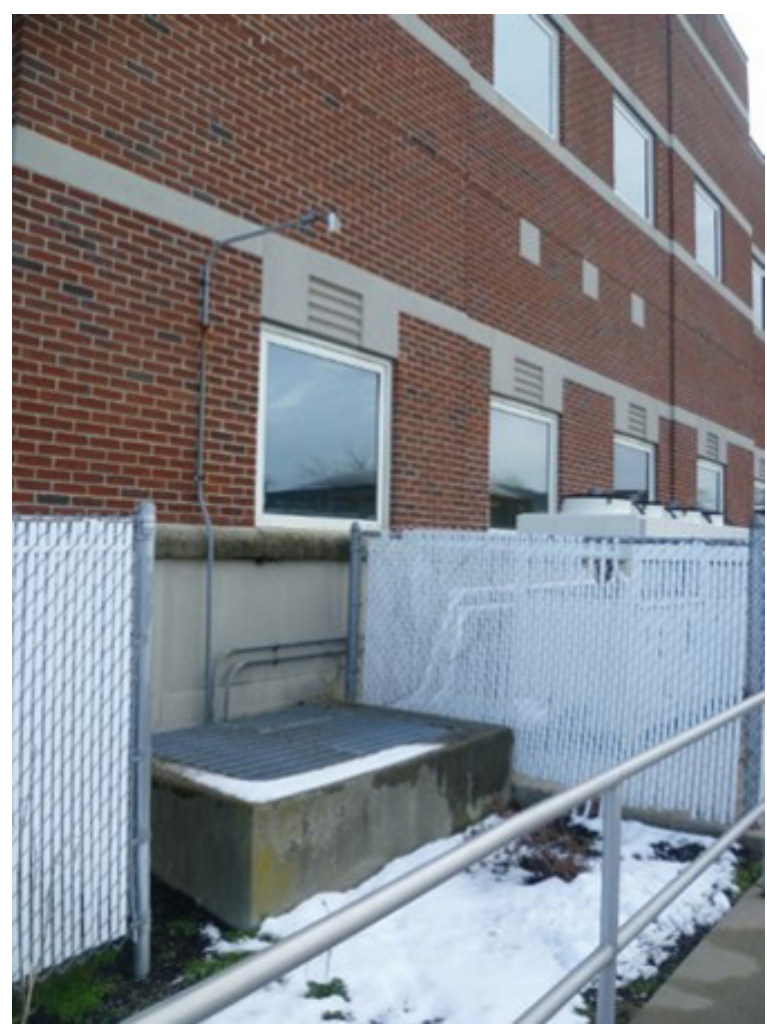

Figure A7. Outdoor air intake for MRI Suites ventilation unit, which was at grade. Photo by NIOSH.

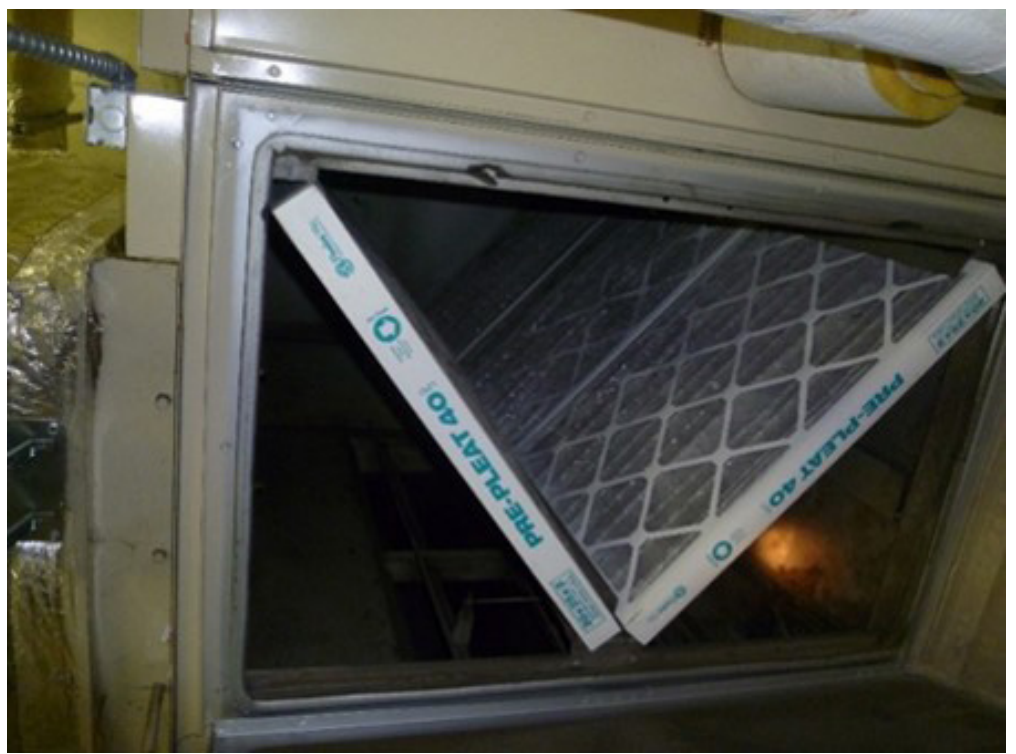

Figure A8. The filters for the MRI Suites ventilation system were tight-fitting and in a V-pattern. Photo by $\mathrm{NIOSH}$. 


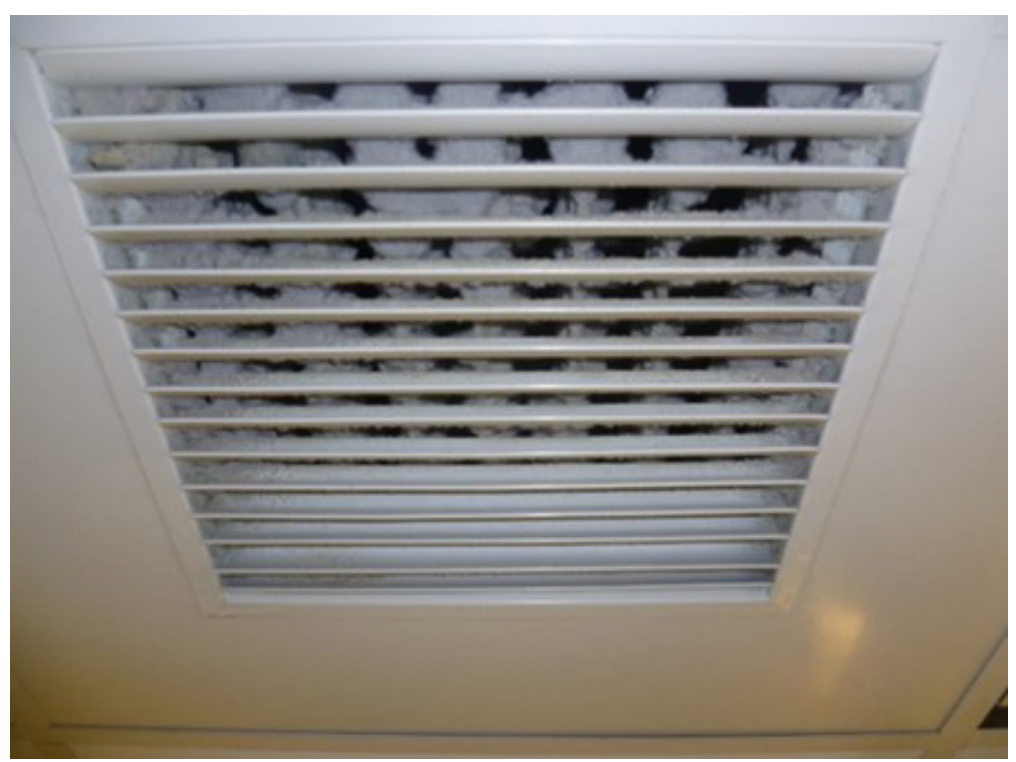

Figure A9. The supply vent shows a gray fibrous material inside the louvers. Photo by NIOSH.

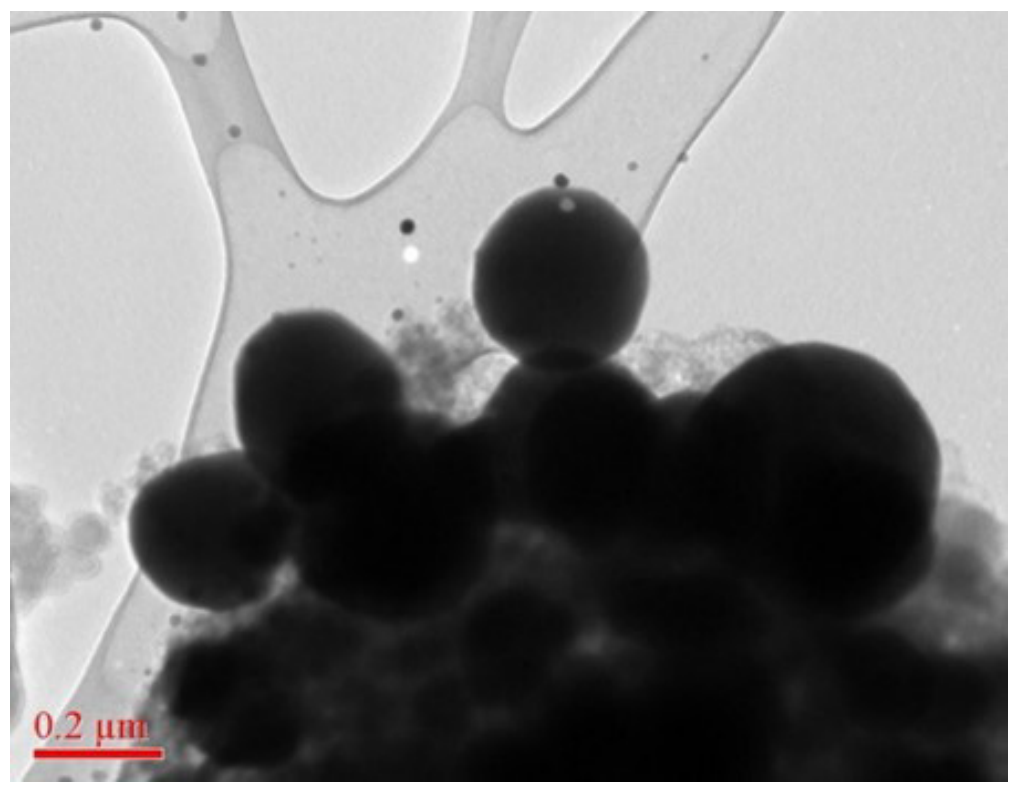

Figure A10. Transmission electron microscopy image of soot and polymer material from MRI changing area. Photo by $\mathrm{NIOSH}$. 


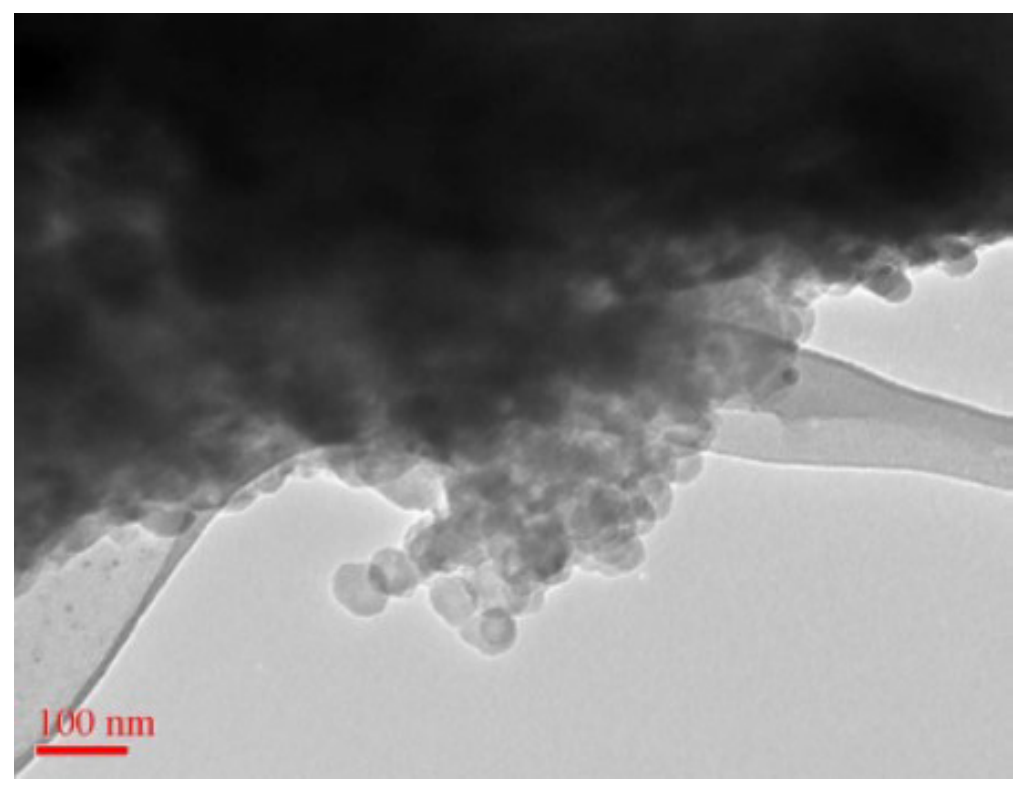

Figure A11. Transmission electron microscopy image of soot from MRI filing room. Photo by NIOSH. 


\section{References}

ACGIH [2018]. 2018 TLVs ${ }^{\circledR}$ and BEIs ${ }^{\circledR}$ : threshold limit values for chemical substances and physical agents and biological exposure indices. Cincinnati, OH: American Conference of Governmental Industrial Hygienists.

ANSI/ASHRAE [2016]. Ventilation for acceptable indoor air quality. American National Standards Institute/ASHRAE standard 62.1-2016. Atlanta, GA: ASHRAE.

ANSI/ASHRAE [2017]. Thermal environmental conditions for human occupancy. American National Standards Institute/ASHRAE standard 55-2017. Atlanta, GA: ASHRAE.

ANSI/ASHRAE/ASHE [2017]. Ventilation of health care facilities. American National Standards Institute/ASHRAE/ASHRAE standard 170-2017. Atlanta, GA: ASHRAE.

ASHRAE [2013]. HVAC design manual for hospitals and clinics. 2nd edition. Atlanta, GA: ASHRAE.

Beach JR, Raven J, Ingram C, Bailey M, Johns D, Walters EH, Abramson M [1997]. The effects on asthmatics of exposure to a conventional water-based and a volatile organic compound-free paint. Eur Respir J 10(3):563-566, http://erj.ersjournals.com/content/erj/10/3/563.full.pdf.

Birch ME [2018]. Monitoring of diesel particulate exhaust in the workplace. In: NIOSH manual of analytical methods (NMAM $\left.{ }^{\circledR}\right)$. 5th ed. Ashley K, O’Connor PF, eds. Cincinnati, OH: U.S. Department of Health and Human Services, Centers for Disease Control and Prevention, National Institute for Occupational Safety and Health, DHHS (NIOSH) Publication No. 2014-151, https://www.cdc.gov/niosh/docs/2014-151/pdfs/chapters/chapter-dl.pdf.

Boxer PA [1990]. Indoor air quality: a psychosocial perspective. J Occup Med 32(5):425-428, https://doi.org/10.1097/00043764-199005000-00007.

Brightman HS, Milton DK, Wypij D, Burge HA, Spengler JD [2008]. Evaluating building related symptoms using the US EPA BASE study results. Indoor Air 18(4):335-345, https://doi.org/10.1111/j.1600-0668.2008.00557.x.

Gamble J, Jones W, Mishall S [1987]. Epidemiological-environmental study of diesel bus garage workers: acute effects of $\mathrm{NO}_{2}$ and respirable particulate on the respiratory system. Environ Res 42(1):201-214, https://doi.org/10.1016/S0013-9351(87)80022-1.

Ghanizadeh F; Godini H [2018]. A review of the chemical and biological pollutants in indoor air in hospitals and assessing their effects on the health of patients, staff and visitors. Rev Environ Health (ahead of print), https://doi.org/10.1515/reveh-2018-0011.

International Agency for Research on Cancer [2012]. IARC: diesel engine exhaust carcinogenic. Lyon, France: World Health Organization, International Agency for Research on Cancer, http://www.iarc.fr/en/media-centre/pr/2012/pdfs/pr213 E.pdf. 
Mendell MJ [1993]. Non-specific symptoms in office workers: a review and summary of the epidemiologic literature. Indoor Air 3(4):227-236, https://doi.org/10.1111/j.1600-0668.1993.00003.x.

NIOSH [2018]. NIOSH manual of analytical methods (NMAM). 5th ed. O'Connor PF, Ashley K, eds. Cincinnati, OH: U.S. Department of Health and Human Services, Centers for Disease Control and Prevention, National Institute for Occupational Safety and Health, DHHS (NIOSH) Publication No. 2014-151, http://www.cdc.gov/niosh/nmam.

Pronk A, Coble J, Stewart PA [2009]. Occupational exposure to diesel engine exhaust: a literature review. J Expo Sci Environ Epidemiol 19(5):443-457, http://dx.doi.org/10.1038/jes.2009.21.

Reger R, Hancock J [1980]. Coal miners exposed to diesel exhaust emissions. In: Rom W, Archer V, eds. Health implications of new energy technologies. Ann Arbor, MI: Ann Arbor Science Publishers, Inc., pp. 212-231.

Schiffman SS, Williams CM [2005]. Science of odor as a potential health issue. J Environ Qual 34(1):129-138, https://static1.squarespace.com/static/54806478e4b0dc44e1698e88/t/55e0c69fe4b098524629 92d9/1440794271771/SchiffmanOdorsJEQJan05.pdf.

Sydbom A, Blomberg A, Parnia S, Stenfors N, Sandström T, Dahlén SE [2001]. Health effects of diesel exhaust emissions. Eur Respir J 17(4):733-746, http://erj.ersjournals.com/content/erj/17/4/733.full.pdf.

Ulfvarson U, Alexandersson R [1990]. Reduction in adverse effect on pulmonary function after exposure to filtered diesel exhaust. Am J Ind Med 17(3):341-347, https://doi.org/10.1002/ajim.4700170306.

U.S. Environmental Protection Agency [2002]. Health assessment document for diesel engine exhaust. Washington, DC: National Center for Environmental Assessment, Office of Transportation and Air Quality, U.S. Environmental Protection Agency Publication No. EPA/600/8-90/057F.

U.S. Environmental Protection Agency [2008]. Code of Federal Regulations, Title 40, Part 50. National Ambient Air Quality Standards.

Vecchio-Sudus AM, Griffiths S [2004]. Marketing strategies for enhancing safety culture. Safety Science 42(7):601-619, https://doi.org/10.1016/j.ssci.2003.11.001.

Wolkoff P, Kjaergaard SK [2007]. The dichotomy of relative humidity on indoor air quality. Environ Int 33(6):850-857, https://dx.doi.org/10.1016/j.envint.2007.04.004. 
Keywords: North American Industry Classification System (NAICS) 622110 (General Medical and Surgical Hospitals); New York; Indoor Environmental Quality, IEQ, Ventilation, Particulate Matter, Diesel Exhaust, Eye Irritation, Nasal Irritation, Throat Irritation 
The Health Hazard Evaluation Program investigates possible health hazards in the workplace under the authority of the Occupational Safety and Health Act of 1970 (29 U.S.C. § 669(a) (6)). The Health Hazard Evaluation Program also provides, upon request, technical assistance to federal, state, and local agencies to investigate occupational health hazards and to prevent occupational disease or injury. Regulations guiding the Program can be found in Title 42, Code of Federal Regulations, Part 85; Requests for Health Hazard Evaluations (42 CFR Part 85).

\section{Disclaimer}

The recommendations in this report are made on the basis of the findings at the workplace evaluated and may not be applicable to other workplaces.

Mention of any company or product in this report does not constitute endorsement by NIOSH.

Citations to Web sites external to NIOSH do not constitute NIOSH endorsement of the sponsoring organizations or their programs or products. NIOSH is not responsible for the content of these Web sites. All Web addresses referenced in this document were accessible as of the publication date.

\section{Acknowledgments}

Analytical Support: Eileen Birch and Joseph Fernback, CDC; Maxxam Analytics

Desktop Publisher: Shawna Watts

Industrial Hygiene Field Assistance: Karl Feldmann

Logistics: Donnie Booher and Kevin Moore

\section{Availability of Report}

Copies of this report have been sent to the employer and employees at the facility. The state and local health department and the Occupational Safety and Health Administration Regional Office have also received a copy. This report is not copyrighted and may be freely reproduced.

\section{Recommended citation for this report:}

NIOSH [2018]. Evaluation of indoor environmental quality concerns among hospital employees working in a radiology department. By Burton NC, Tapp L. Cincinnati, OH: U.S. Department of Health and Human Services, Centers for Disease Control and Prevention, National Institute for Occupational Safety and Health, Health Hazard Evaluation Report 2016-0176-3326, https://www.cdc.gov/niosh/hhe/reports/pdfs/2016-0176-3326.pdf. 
Delivering on the Nation's promise:

Promoting productive workplaces through safety and health research

To receive NIOSH documents or more information about occupational safety and health topics, please contact NIOSH:

Telephone: 1-800-CDC-INFO (1-800-232-4636)

TTY: 1-888-232-6348

CDC INFO: www.cdc.gov/info

or visit the NIOSH Web site at www.cdc.gov/niosh

For a monthly update on news at $\mathrm{NIOSH}$, subscribe to

$\mathrm{NIOSH}$ eNews by visiting www.cdc.gov/niosh/eNews. 